\title{
Metode Multi Objective Optimization by Ratio Analysis Dalam Penentuan Penerima Kartu Jakarta Pintar
}

\author{
Mely Mailasari ${ }^{1)}$, Khoirun Nisa ${ }^{2)}$ \\ 1) Prodi Sistem Informasi, Fakultas Teknik dan Informatika, Universitas Bina Sarana \\ Informatika \\ Jl. Kramat Raya No. 98, Senen, Jakarta Pusat \\ ${ }^{2)}$ Prodi Sistem Informasi, Sekolah Tinggi Manajemen Informatika dan Komputer Nusa Mandiri \\ Jakarta \\ 1) mely.myl@bsi.ac.id \\ ${ }^{2)}$ khoirun.khn@nusamandiri.ac.id
}

\begin{abstract}
Abstrak
Program bantuan pemerintah salah satunya melalui Kartu Jakarta Pintar (KJP) yaitu memberi bantuan biaya pendidikan untuk memenuhi semua kebutuhan siswa dengan menggunakan kartu. Program ini ditujukan untuk anak usia sekolah dasar hingga menengah atas atau sederajat yang berasal dari keluarga yang tidak mampu. Dalam pelaksanaan program ini ditemui beberapa kendala dan penyalahgunaan seperti penilaian yang subjektif sehingga program Kartu Jakarta Pintar menjadi tidak tepat sasaran. Karena permasalahan diatas, dibutuhkan sebuah sistem pendukung keputusan pada penelitian ini menggunakan metode Multi Objective Optimization by Ratio Analysis (MOORA) untuk menentukan penerima Kartu Jakarta Pintar (KJP) yang tepat sasaran sehingga terhindar dari penyalahgunaan tujuan program. Metode MOORA digunakan untuk menghitung nilai bobot setiap atribut, proses perankingan akan melakukan seleksi alternatif penerima Kartu Jakarta Pintar (KJP) dari semua alternatif yang ada sesuai dengan kriteria yang sudah ditentukan berdasarkan hasil perhitungan nilai Yi tertinggi. Kriteria yang dimaksud antara lain jumlah saudara usia kurang dari 18 tahun, pendapatan rumah tangga dan asset yang dimiliki. Dari hasil perhitungan didapatkan nilai Yi tertinggi sebagai alternatif terbaik pada alternatif A6 dengan nilai sebesar 0,646263946 yang diprioritaskan untuk mendapat Kartu Jakarta Pintar (KJP).
\end{abstract}

Kata kunci: DSS, MOORA, Penerima KJP

\begin{abstract}
One of the government assistance programs is the Kartu Jakarta Pintar (KJP) which is to provide tuition assistance to meet all student needs by using card. This program is aimed at children of elementary to high school age or equivalent who come from poor families. Because of the above problems, a decision support system is needed in this study using the Multi Objective Optimization by Ratio Analysis (MOORA) method to determine the right Kartu Jakarta Pintar $(K J P)$ recipient to avoid misuse of program objectives. The MOORA method is used to calculate the weight value of each attribute, the ranking process will select Kartu Jakarta Pintar (KJP) recipient alternatives from all available alternatives according to predetermined criteria based on the calculation of the highest Yi value. The criteria referred to include, among others, the number of relatives aged less than 18 years, household income, and assets owned. From the calculation results, the highest Yi value is obtained as the best alternative to the A6 alternative with a value of 0.646263946 which is prioritized to get Kartu Jakarta Pintar (KJP),
\end{abstract}

Keywords: DSS, MOORA, KJP Recipients 


\section{PENDAHULUAN}

Kartu Jakarta Pintar (KJP) merupakan Program Bantuan Biaya Personal Pendidikan yang diharapkan membuat peserta didik tetap dapat melanjutkan pendidikan sampai tamat sejak dasar hingga menengah atas serta menarik minat siswa putus sekolah untuk kembali melanjutkan pendidikan. Biaya pendidikan yang tinggi membuat banyak peserta didik tidak dapat melanjutkan sekolah dan tingginya angka putus sekolah (drop out) sehingga mempengaruhi Angka Partisipasi Kasar (APK).

Madrasah Ibtidaiyah yang ada di Jakarta merupakan salah satu yang mengikuti Program Bantuan Biaya Personal Pendidikan melalui KJP. Namun, untuk menentukan kandidat penerima KJP pihak sekolah terkadang melakukan penilaian secara subjektif sehingga penerima KJP menjadi tidak sesuai. Dari masalah yang ada dibutuhkan sebuah pemecahan masalah berupa sistem pendukung keputusan untuk memilih kandidat penerima KJP yang sesuai dengan kriteria. Perpaduan kecerdasan manusia yang memiliki kemampuan komponen memperbaiki kualitas keputusan dengan tujuan sebagai penyedia informasi, memberikan gambaran serta mengarahkan pengguna informasi agar mengambil keputusan lebih baik disebut sebagai sistem pendukung keputusan. Metode sistem pendukung keputusan sangat banyak, dalam penelitian ini metode yang digunakan adalah metode Multi-Objective Optimization On The Basis Of Ratio Analysis (MOORA). Beberapa penelitian terdahulu menyebutkan bahwa penggunaan metode MOORA untuk melakukan perhitungan kriteria-kriteria sebagai syarat pengajuan KPR sehingga memudahkan calon debitur dalam mengambil keputusan[1], metode MOORA digunakan dalam menentukan perangkingan stok jenis mobil oleh perusahaan yang akan berpengaruh terhadap kepuasan pelanggan yang akan membeli produk tersebut[2].

Penelitian mengenai proses evaluasi kinerja guru yang didasarkan pada kompetensi pedagogis, kepribadian, sosial, dan profesional. Data kemudian dianalisis menggunakan metode Analytical Hierarchy Process (AHP) untuk menentukan bobot setiap kompetensi dan menentukan nilai alternatif tertinggi atau penilaian kinerja guru honorer terbaik berdasarkan bobot yang telah ditentukan dengan memproses peringkat menggunakan metode MOORA[3].

Berdasarkan beberapa penelitian terdahulu diatas penelitian ini membangun sistem pendukung keputusan menggunakan perhitungan metode MOORA yang mudah dipahami dan fleksibel karena memisahkan bagian subjektif dari suatu proses evaluasi ke dalam kriteria bobot dengan beberapa atribut pengambilan keputusan.

\section{TINJAUAN PUSTAKA}

Sistem pendukung keputusan (SPK) biasanya digunakan sebagai solusi atas suatu masalah atau peluang. SPK merupakan penggabungan kecerdasan manusia dengan kemampuan komponen dalam memperbaiki kualitas keputusan[4]. Tujuan SPK yaitu memberikan informasi, gambaran serta arahan kepada pengguna informasi untuk mengambil keputusan yang tepat [5]. Menurut Kusrini, ciri-ciri sistem pendukung keputusan atau decision support system adalah 1). Ditujukan untuk membantu keputusan-keputusan yang kurang terstruktur, 2). Merupakan gabungan antara model kualitatif dan kumpulan data, 3). Bersifat fleksibel dan dapat menyesuaikan dengan perubahan-perubahan yang terjadi[6].

Salah satu metode dalam sistem pendukung keputusan adalah Multi Objective Optimization by Ratio Analysis (MOORA). Metode MOORA dikenalkan oleh Brauers dan Zavadkas pada tahun 2006 yang dapat didefinisikan sebagai optimasi multiobjective atau pemrograman, dikenal juga sebagai multi atribut optimization yaitu teknik pengambilan keputusan yang kompleks dari berbagai masalah dalam lingkungan manufaktur seperti bidang manajemen, pembangunan, kontraktor, arsitektur jalan, dan ekonomi. Metode ini dianggap mudah secara komputasi dan sederhana dalam mengambil keputusan dengan mengeliminasi alternatif yang tidak sesuai dan memilih alternatif yang paling tepat sesuai kriteria yang ditentukan[7]. Cara kerja MOORA dimulai dari menentukan nilai kriteria, bobmatriks ternormalisasi, mengurangi nilai maximax dan minmax dan menentukan ranking dari hasil perhitungan[2]. 


\section{METODE PENELITIAN}

Menurut R. Attri, dan Grover, S., metode moora pada proses evaluasi memecah bagian subjektif dalam kriteria bobot dan atribut sehingga mudah dimengerti dan fleksibel [8]. Tingkat selektifitas yang tinggi dalam metode MOORA dapat digunakan untuk memilih tujuan dari kriteria yang bersebrangan. Karena terdapat dua kategori parameter yaitu yang berbobot benefit (menguntungkan) atau berbobot cost (tidak menguntungkan)[2]. Berbagai bidang pada kehidupan sehari-hari seperti bidang manajemen, pembangunan kontraktor, arsitektur jalan dan perekonomian dapat menerapkan pengambilan keputusan menggunakan metode MOORA. Pendekatan dengan MOORA diasumsikan sebagai proses pengoptimalan secara bersamaan beberapa kriteria yang saling bersebrangan pada beberapa masalah[9].

Lima langkah utama pada metode MOORA yaitu pertama, menentukan atribut dan tujuan dari permasalahan yang diangkat. Kedua, menyajikan informasi yang ada sebagai parameter kemudian membentuk sebuah matriks keputusan. Hasil data yang diperoleh dari persamaan 1 ditampilkan sebagai matriks x. Setelah itu dibuat perbandingan setiap hasil dari alternatif pada parameter dengan penyebut yang mewakili parameter tersebut dirumuskan pada persamaan 1 berikut:

$X=\left[\begin{array}{cccc}X_{11} & X_{12} & \cdot & X_{1 N} \\ X_{21} & X_{22} & \cdot & X_{2 N} \\ \cdot & \cdot & \cdot & \cdot \\ X_{M 1} & X_{M 2} & \cdot & X_{M N}\end{array}\right]$

Ketiga, untuk penyebut atribut terbaik dipilih hasil akar kuadrat dari perhitungan jumlah kuadrat pada setiap alternatif di setiap atribut yang dirumuskan pada persamaan 2.

$X^{*}{ }_{i j}=\frac{X_{i j}}{\sqrt{\left[\sum_{j=1}^{m} X_{i j}^{2}\right]}}$

Keterangan:

$\mathrm{X} * \mathrm{ij}=$ Matriks normalisasi alternatif i pada kriteria $\mathrm{j}$

$\mathrm{X}_{\mathrm{ij}}=$ Matriks alternatif $\mathrm{i}$ pada kriteria $\mathrm{j}$

$\mathrm{i}=$ alternatif

$\mathrm{j}=$ kriteria

Deretan ke-i dari alternatif pada kriteria $\mathrm{j}$ disebut $\mathrm{Xij}$, $\mathrm{m}$ adalah penjumlahan alternatif keseluruhan dan $\mathrm{n}$ merupakan kuantitas kriteria. Keempat, hasil normalisasi merupakan penjumlahan maksimal dari atribut benefit (menguntungkan) dan hasil pengurangan minimal dari atribut cost (tidak menguntungkan). Kemudian untuk optimasi dirumuskan dalam persamaan 3:

$Y_{i}=\sum_{i=1}^{y} X_{i j}-\sum_{j=g+1}^{n} X_{i j}$

g menunjukkan maksimum jumlah atribut, (n-g) adalah jumlah atribut minimum, dan $\mathrm{Y}_{\mathrm{i}}$ merupakan hasil nilai normalisasi alternatif i pada setiap atribut. Dengan maksud hasil pengurangan nilai maksimum dan nilai minimum pada setiap baris untuk menentukan peringkat pada setiap baris tersebut. Pembobotan ini menggunakan rumus pada persamaan 4 berikut:

$Y_{i}=\sum_{i=1}^{y} W_{j} X_{i j}-\sum_{j=g+1}^{n} W_{j} X_{i j}$

Wj merupakan bobot pada atribut j, Parameter maksimal (yang meguntungkan) dan parameter minimal (yang tidak menguntungkan) dapat menentukan nilai Yi dalam matriks keputusan menjadi positif atau negatif. Hasil perhitungan dengan metode MOORA yaitu nilai Yi tertinggi yang merupakan pilihan terbaik didapat dari pemilihan alternatif sesuai dengan permasalah yang 
ada sedangkan nilai Yi terendah didapat dari nilai alternatif terkecil pada data yang ada merupakan pilihan terburuk dalam pengambilan keputusan.

\section{PEMBAHASAN}

Pada pemilihan penerimaan Kartu Jakarta Pintar (KJP) tidak sepenuhnya melalui tahap seleksi sesuai prosedur sehingga ada ketidakadilan dalam pengambilan keputusannya. Dengan demikian, penelitian ini akan merancang sebuah sistem pendukung keputusan dalam penentuan penerima KJP.

Pertama yang dilakukan dalam melakukan perhitungan menggunakan metode MOORA yaitu memilih parameter-parameter penilaian yang dapat dilihat pada tabel 1 berikut:

Tabel 1. Kriteria

\begin{tabular}{clcl}
\hline Kriteria & \multicolumn{1}{c}{ Keterangan } & Bobot & \multicolumn{1}{c}{ Jenis } \\
\hline C1 & Jumlah Saudara Kandung & $30 \%$ & Benefit \\
C2 & Pendapatan Orang Tua & $40 \%$ & Benefit \\
C3 & Aset & $30 \%$ & Cost
\end{tabular}

Sumber: Hasil Penelitian (2020)

Pada tabel 1. dijelaskan ada 3 kriteria yang digunakan dalam penentuan penerima KJP dimana ada 2 jenis benefit dan 1 cost. Langkah selanjutnya menentukan kriteria penilaian untuk setiap alternatif yang kemudian nilai dari setiap kriteria tersebut diubah kedalam skala likert untuk memudahkan pengolahan data dengan ketentuan berikut:

Tabel 2. Skala Penilaian

\begin{tabular}{llll}
\hline \multicolumn{1}{c}{ Kode } & \multicolumn{1}{c}{ Nama Kriteria } & \multicolumn{1}{c}{ Keterangan } & Skala Penilaian \\
\hline C1 & Jumlah Saudara Kandung & Tidak Punya & 1 \\
& & 1 & 2 \\
& 2 & 3 \\
& & & 4 \\
C2 & \multirow{2}{*}{ Pendapatan RT } & 3 & 5 \\
& & $1.000 .000-2.500 .000$ & 1 \\
& & $2.500 .000-4.000 .000$ & 3 \\
C3 & \multirow{2}{*}{ Aset yang dimiliki } & Lebih dari 4.000.000 & 4 \\
& & Tidak Punya & 1 \\
& & Punya Motor & 2 \\
& & Punya Rumah & 3 \\
& & Punya Motor dan Rumah & 4 \\
\hline
\end{tabular}

Sumber: [10]

Berdasarkan nilai yang sudah disesuaikan dalam skala angka likert diperoleh matriks keputusan X sebagai berikut:

$$
X_{i j}=\left[\begin{array}{lll}
1 & 1 & 3 \\
3 & 2 & 1 \\
3 & 1 & 4 \\
1 & 1 & 1 \\
1 & 2 & 2 \\
4 & 1 & 1 \\
3 & 2 & 1 \\
2 & 2 & 2 \\
2 & 1 & 1 \\
3 & 1 & 3
\end{array}\right]
$$


Berikut adalah hasil perhitungan nilai setiap kriteria disebut normalisasi matriks $\mathrm{X}$ menggunakan persamaan 2:

$$
\begin{aligned}
& C 1=\sqrt{1^{2}+3^{2}+3^{2}+1^{2}+1^{2}+4^{2}+3^{2}+2^{2}+2^{2}+3^{2}} \\
& C 1=7,937253933 \\
& A_{11}=\frac{1}{7,937253933} \\
& A_{11}=0,125988158 \\
& A_{16}=\frac{4}{7,937253933} \\
& A_{16}=2,015810523 \\
& A_{12}=\frac{3}{7,937253933} \\
& A_{12}=1,133893419 \\
& A_{17}=\frac{3}{7,937253933} \\
& A_{17}=1,133893419 \\
& A_{13}=\frac{3}{7,937253933} \\
& A_{13}=1,133893419 \\
& A_{18}=\frac{2}{7,937253933} \\
& A_{18}=0,503952631 \\
& A_{14}=\frac{1}{7,937253933} \\
& A_{19}=\frac{2}{7,937253933} \\
& A_{14}=0,125988158 \\
& A_{19}=0,503952631 \\
& \begin{array}{l}
A_{15}=\frac{1}{7,937253933} \\
A_{15}=0,125988158
\end{array} \\
& A_{110}=\frac{3}{7,937253933} \\
& A_{110}=1,133893419 \\
& C 2=\sqrt{1^{2}+2^{2}+1^{2}+1^{2}+2^{2}+1^{2}+2^{2}+2^{2}+1^{2}+1^{2}} \\
& C 2=4,69041576 \\
& A_{21}=\frac{1}{4,69041576} \\
& A_{21}=0,213200716 \\
& A_{26}=\frac{1}{4,69041576} \\
& A_{22}=\frac{2}{4,69041576} \\
& A_{22}=0,852802865 \\
& A_{26}=0,213200716 \\
& A_{23}=\frac{1}{4,69041576} \\
& A_{23}=0,213200716 \\
& A_{27}=\frac{2}{4,69041576} \\
& A_{27}=0,852802865 \\
& A_{24}=\frac{1}{4,69041576} \\
& A_{24}=0,213200716 \\
& A_{28}=\frac{2}{4,69041576} \\
& A_{28}=0,852802865 \\
& A_{25}=\frac{2}{4,69041576} \\
& A_{25}=0,852802865 \\
& A_{29}=\frac{1}{4,69041576} \\
& A_{29}=0,213200716 \\
& A_{210}=\frac{1}{4,69041576} \\
& A_{210}=0,213200716 \\
& C 3=\sqrt{3^{2}+1^{2}+4^{2}+1^{2}+2^{2}+1^{2}+1^{2}+2^{2}+1^{2}+3^{2}} \\
& C 3=6,8556546 \\
& A_{31}=\frac{3}{6,8556546} \\
& A_{31}=1,312784923 \\
& A_{36}=\frac{1}{6,8556546} \\
& A_{36}=0,145864991 \\
& \begin{aligned}
A_{32} & =\frac{1}{6,8556546} \\
A_{32} & =0,145864991
\end{aligned} \\
& A_{37}=\frac{1}{6,8556546} \\
& A_{37}=0,145864991
\end{aligned}
$$




$$
\begin{aligned}
A_{33} & =\frac{4}{6,8556546} \\
A_{33} & =2,333839864 \\
A_{34} & =\frac{1}{6,8556546} \\
A_{34} & =0,145864991 \\
A_{35} & =\frac{2}{6,8556546} \\
A_{35} & =0,583459966
\end{aligned}
$$

$$
\begin{aligned}
& A_{38}=\frac{2}{6,8556546} \\
& A_{38}=0,583459966 \\
& A_{39}=\frac{1}{6,8556546} \\
& A_{39}=0,145864991 \\
& A_{310}=\frac{3}{6,8556546} \\
& A_{310}=1,312784923
\end{aligned}
$$

Selanjutnya menentukan Matriks Normalisasi terbobot menggunakan persamaan 3 diperoleh hasil seperti berikut:

$$
\begin{aligned}
& C 1= A 1: 0,3 \times 0,125988158=0,037796447 \\
& A 2: 0,3 \times 1,133893419=0,340168026 \\
& A 3: 0,3 \times 1,133893419=0,340168026 \\
& A 4: 0,3 \times 0,125988158=0,037796447 \\
& A 5: 0,3 \times 0,125988158=0,037796447 \\
& A 6: 0,3 \times 2,015810523=0,604743157 \\
& A 7: 0,3 \times 1,133893419=0,340168026 \\
& A 8: 0,3 \times 0,503952631=0,151185789 \\
& A 9: 0,3 \times 0,503952631=0,151185789 \\
& A 10: 0,3 \times 1,133893419=0,340168026 \\
& C 2=A 1: 0,4 \times 0,213200716=0,085280287 \\
& A 2: 0,4 \times 0,852802865=0,341121146 \\
& A 3: 0,4 \times 0,213200716=0,085280287 \\
& A 4: 0,4 \times 0,213200716=0,085280287 \\
& A 5: 0,4 \times 0,852802865=0,341121146 \\
& A 6: 0,4 \times 0,213200716=0,085280287 \\
& A 7: 0,4 \times 0,852802865=0,341121146 \\
& A 8: 0,4 \times 0,852802865=0,341121146 \\
& A 9: 0,4 \times 0,213200716=0,085280287 \\
& A 10: 0,4 \times 0,213200716=0,085280287
\end{aligned}
$$$$
C 3=A 1: 0,3 \times 1,312784923=0,393835477
$$$$
A 2: 0,3 \times 0,145864991=0,043759497
$$$$
A 3: 0,3 \times 2,333839864=0,700151959
$$$$
A 4: 0,3 \times 0,145864991=0,043759497
$$$$
A 5: 0,3 \times 0,583459966=0,17503799
$$$$
A 6: 0,3 \times 0,145864991=0,043759497
$$$$
A 7: 0,3 \times 0,145864991=0,043759497
$$$$
A 8: 0,3 \times 0,583459966=0,17503799
$$$$
A 9: 0,3 \times 0,145864991=0,043759497
$$$$
A 10: 0,3 \times 1,312784923=0,393835477
$$

Setelah mendapat nilai pembobotan dilakukan perhitungan nilai $Y_{i}$ menggunakan persamaan 4. sebagai berikut:

Tabel 3. Nilai Yi

\begin{tabular}{ccccc}
\hline Alternatif & $\begin{array}{c}\text { Max } \\
(\mathrm{C} 1+\mathrm{C} 2+\mathrm{C} 4)\end{array}$ & Min $(\mathrm{C} 3)$ & $\begin{array}{c}\text { Yi= Max- } \\
\text { Min }\end{array}$ & Rank \\
\hline A6 & 0,690023443 & 0,043759497 & 0,646263946 & 1 \\
A2 & 0,681289172 & 0,043759497 & 0,637529674 & 2 \\
A7 & 0,681289172 & 0,043759497 & 0,637529674 & 3 \\
A8 & 0,492306935 & 0,17503799 & 0,317268946 & 4 \\
A5 & 0,378917593 & 0,17503799 & 0,203879604 & 5 \\
A9 & 0,236466076 & 0,043759497 & 0,192706578 & 6 \\
A4 & 0,123076734 & 0,043759497 & 0,079317236 & 7 \\
A10 & 0,425448312 & 0,393835477 & 0,031612835 & 8 \\
A1 & 0,123076734 & 0,393835477 & $-0,270758743$ & 9 \\
A3 & 0,425448312 & 0,700151959 & $-0,274703647$ & 10 \\
\hline
\end{tabular}

Sumber: Hasil Penelitian (2020)

Pada tabel 3. dilakukan perhitungan Yi dengan mencari terlebih dahulu nilai MAX yang didapat dari penjumlahan bobot benefit $\mathrm{C} 1, \mathrm{C} 2$ dan $\mathrm{C} 4$ kemudian dikurangi bobot cost $\mathrm{C}$. Dari proses perhitungan diperoleh hasil nilai Yi berupa nilai positif dan negatif, nilai Yi tertinggi merupakan 
kandidat prioritas yang akan mendapatkan KJP berada pada alternatif A6 dengan nilai 0,646263946 sedangkan nilai Yi terendah ada pada alternatif A3 dengan nilai -0,274703647yang artinya kandidat yang paling terakhir dilihat dalam penentuan penerima KJP.

\section{KESIMPULAN}

Berdasarkan penelitian diatas dapat ditarik kesimpulan bahwa dengan sistem pendukung keputusan yang sedang berjalan masih dilakukan dengan penilaian secara subjektif dan sangat sederhana, maka solusi dari peneliti yaitu dengan menggunakan metode pengambilan keputusan Multi-Objective Optimization On The Basis Of Ratio Analysis (MOORA). MOORA adalah metode yang sesuai dalam sebuah seleksi penerima KJP karena pengolahan data yang cepat dan tepat sesuai dengan yang diharapkan.

Berdasarkan kriteria-kriteria yang ditentukan dan melalui proses perhitungan maka didapat nilai bobot kriteria tertinggi adalah pendapatan orang tua (benefit) yaitu sebesar $40 \%$. Langkah selanjutnya menentukan kriteria penilaian untuk setiap alternatif, kemudian nilai dari masingmasing kriteria tersebut diubah kedalam skala likert untuk memudahkan pengolahan data. Pada normalisasi matriks $X$ perhitungan nilai setiap kriteria menggunakan persamaan nomor 2 menghasilkan nilai pembobotan, langkah terakhir dilakukan perhitungan nilai Yi sehingga diperoleh nilai $\mathrm{Yi}$ tertinggi sebagai alternatif terbaik adalah data alternatif A6 sebesar 0,646263946 yang diprioritaskan untuk mendapat KJP sedangkan nilai Yi terendah sebagai alternatif terburuk ada pada data alternatif A3 sebesar -0,274703647 yang artinya menjadi kandidat yang paling terakhir dilihat dalam penentuan penerima KJP.

\section{DAFTAR PUSTAKA}

[1] N. W. Al-Hafiz, Mesran, and Suginam, "Sistem Pendukung Keputusan Penentukan Kredit Pemilikan Rumah Menerapkan Multi-Objective Optimization on the Basis of Ratio Analysis ( Moora )," KOMIK (Konferensi Nas. Teknol. Inf. dan Komputer), vol. I, no. 1, pp. 306-309, 2017.

[2] H. Indriyawati, S. R. Cholil, V. G. Utomo, P. Studi, S. Informasi, and U. Semarang, "Penentuan Prediksi Stok Mobil Dengan Pendekatan Kepuasan Pelanggan Menggunakan Metode Moora," Telematika, vol. 11, no. 2, pp. 55-64, 2018.

[3] S. Fadli and K. Imtihan, "Implementation of MOORA Method in Evaluating Work Performance of Honorary Teachers," SinkrOn, vol. 4, no. 1, p. 128, 2019.

[4] S. Wardani, I. Parlina, and A. Revi, "ANALISIS PERHITUNGAN METODE MOORA DALAM PEMILIHAN SUPPLIER BAHAN BANGUNAN DI TOKO MEGAH GRACINDO JAYA InfoTekJar ( Jurnal Nasional Informatika dan Teknologi Jaringan )," J. Nas. Inform. dan Teknol. Jar., vol. 3, no. 1, pp. 95-99, 2018.

[5] S. Rokhman, I. F. Rozi, and R. A. Asmara, "Pengembangan Sistem Penunjang Keputusan Penentuan Ukt Mahasiswa Dengan Menggunakan Metode Moora Studi Kasus Politeknik Negeri Malang," J. Inform. Polinema, vol. 3, no. 4, p. 36, 2017.

[6] M. Mailasari, "Model Multi Attribute Decision Making Metode Simple Additive Weighting Dalam Penentuan Penerima Pinjaman," J. Tek. Komput., vol. 2, no. 1, pp. 100105, 2016.

[7] M. Sinaga, "Sistem Pendukung Keputusan Pemilihan Curling Iron Terbaik Dengan Menerap Kan Metode MOORA (Multi Objective Optimization On The Basis Of Rasio Analysis) (Studi Kasus New Beauty Toko)," Pelita Inform. Budi Darma, vol. 16, no. 4, pp. 444-449, 2017.

[8] S. Manurung, "Sistem Pendukung Keputusan Pemilihan Guru Dan Pegawai Terbaik Menggunakan Metode Moora," Simetris J. Tek. Mesin, Elektro dan Ilmu Komput., vol. 9, no. 1, pp. 701-706, 2018.

[9] A. A. Saputri, N. Dengen, and Islamiyah, "Sistem Pendukung Keputusan Penentuan Dosen Pengampu Mata Kuliah Dengan Metode MOORA," vol. 3, no. 1, pp. 11-19, 2019. 
[10] "Instrumen Kunjungan Sekolah Untuk Tinjauan Lapangan/Verifikasi Faktual Calon Penerima Bantuan Biaya Personal Pendidikan Melalui Kartu Jakarta Pintar,” pp. 6-9, 2019.

\section{Biodata Penulis}

Mely Mailasari, Lahir di Jakarta 27 Mei 1989. Meraih gelar Sarjana Komputer (S.Kom) di STMIK Nusa Mandiri Jakarta tahun 2012, Kemudian mendapatkan gelar Magister Komputer (M.Kom) di STMIK Nusa Mandiri Jakarta tahun 2015. Saat ini bekerja sebagai dosen Program Studi Sistem Informasi Universitas Bina Sarana Informatika.

Khoirun Nisa, Lahir di Jakarta 14 Juni 1990. Meraih gelar Sarjana Komputer (S.Kom) di STMIK Nusa Mandiri Jakarta tahun 2014, Kemudian mendapatkan gelar Magister Komputer (M.Kom) di STMIK Nusa Mandiri Jakarta tahun 2016. Saat ini bekerja sebagai dosen Program Studi Sistem Informasi STMIK Nusa Mandiri. 